\title{
前方すべりを伴う頝髄症手術例の検討
}

\author{
長崎労災病院整形外科 \\ 小西宏 昭・原真一郎 \\ 山口和 博・北原 博之
}

\section{A Study of Surgical Treatment for Cervical Spondylotic Myelopathy with Degenerative Spondylolisthesis}

\author{
Hiroaki Konishi, Shinichiro Hara, Kazuhiro Yamaguchi \\ and Hiroyuki Kitahara \\ Department of Orthopaedic Surgery, Nagasaki Rousai Hospital, Sasebo, Japan
}

\begin{abstract}
Cervical spondylotic myelopathy with degenerative spondylolisthesis is rare. This paper presents the methods for the surgical treatment of this spinal disorder.

Six cases of degenerative cervical spondylolisthesis with myelopathy were treated by three operative procedures. Three cases were treated by laminoplasty and other cases were treated by two types of spinal fusion. One of the cases treated by laminoplaty showed complications with transient shoulder girdle palsy. Segmental instability in $\mathrm{C} 4 / 5$ was observed by plain radiographs in this case.

We recommended the fusion procedures for a case whose spinal cord was compressed only at the lesion with spondylolisthesis. On the other hand, when the spinal cord was compressed at multi levels, we recommend laminoplasty. Different methods should be used for cases with segmental instability. For example, we recommend laminoplasty combined with spinal fusion or laminoplasty combined with decompression of the nerve root for such cases.
\end{abstract}

Key words : Surgical Treatment (手術的治療), Cervical Spine (䅡椎), Degenerative Spondylolisthesis（変性すべり）

はじめに

頝椎の変性変化の一つに頝椎前方すべりがある. 腰 椎では変性すべり症として, その病態の解明や治療法 の選択について論議されているが, 頚椎での同様な研 究は少ない. 従って, いまだ一つの疾患としては認知 されていないと言える. 手術法に関しても, 通常の頚 髄症とは病態上異なる点が多いことから症例に応じた 工夫が必要となる. 今回, 頚椎すべりを伴った頚䯣症 の手術例を検討し，適切な治療のあり方を考察した。

\section{対象および方法}

1995 年 1 月から 1997 年 12 月の間に当科を受診し た患者で, 頝椎側面中間位レントゲン像により椎体前 後径の $10 \%$ 以上の前方すべりが確認できた 6 例を対 象とした.この中には, 外傷, 慢性関節リウマチ, 腎 透析による破壊性脊椎症, アテトーゼ型頚椎症, 奉椎 腫癔, 頚椎手術後の症例は含まれていない.

これらの症例ですべり部位, 澒椎アライメント, す ベり部位以外の椎間の高度狭小化, 脊柱管前後径, MRI 所見と障害高位との関連, 手術法とその治療成 
績を調査した.

結果

年齢は 48 歳より 83 歳, 平均 71.2 歳, 性別は男性 4 例女性 2 例であった。 すべり部位は C3 が 1 例， C4 が 3 例, C6 が 1 例， C7 が 1 例であった. 頚椎アライ メントは前弯型が 4 例, 後弯型が 2 例であった. 頚椎 椎間腔の $50 \%$ 以上の狭小化は C5/6 では全例にみられ た（図 1 ）。C5 での脊柱管前後径は $11 \mathrm{~mm}$ から 14 $\mathrm{mm}$ で, 平均は $12.9 \mathrm{~mm}$ であった.

次に, MRIによる高位診断と神経学的高位診断が 一致し，しかもそれがすべり部位に特定できたのは 6 例中 3 例であった，術式は頝椎プレートを使用した前 方除圧固定術が 2 例, Pedicle screw を用いた後方か らの除圧と固定が 1 例, 棘突起縦割式椎弓形成術が 3 例であった．椎弓形成術の 1 例で術後に一過性 C5 麻 痺が生じた。平均改善率はそれぞれ 69\%，86\%，52 \%であった。

\section{代表 的症 例}

\section{症例 1（図 2）}

60 歳男性, 何ら誘因なく両下肢痤性麻痖が進行し, 発症より 2 ケ月後に当科を受診, C7 前方すべりによ る脊檤症と診断した. C6 から T1 の脊柱管挔大術と Pedicular screw による固定を行った. 術後 2 年の現 在 JOA score は術前の 4/11 から 10/11 に改善した. 改善率は $86 \%$ であった。

症例 2（図3）

75 歳の男性で 2 年前より頝部痛之両手の巧緻運動 障害が出現し， 3 ケ月前より歩行障害が増強した. C3 から C5 の前方除圧固定術をプレート固定を併用 しておこなった．術後両手巧緻運動障害は残存し，

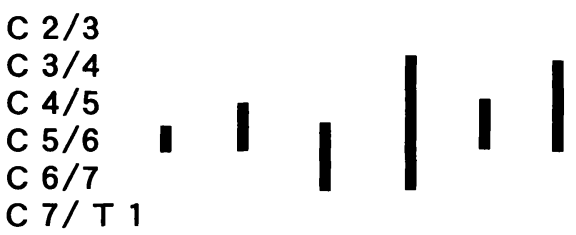

図 1 高度に椎間板変性を呈した部位 椎間板の高度変性により可動性が減少している部位 は全例 C $5 / 6$ 椎間を含み 6 例中 5 例が複数の連続す る椎間に及んでいた。
JOA score は 8 点から 13 点への改善に留まった. 改 善率は $56 \%$ であった.

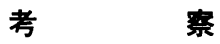

頝椎前方すべりは, 頝椎側面動態撮影の前屈像で, しばしば認められる所見である。 しかし，外傷，慢性 関節リウマチ，破壊性䅡椎症，アテトーゼ型䅡椎症な どを除外した変性変化による頝椎前方すべりが, 頚椎 側面中間位で認められる場合は, 腰椎すべりと比較す ると稀である. しかし，腰椎の場合と同様に脊椎分離 を伴わない前方すべりは神経組織への圧迫因子となる.

これまでにも，前方すべりによる春髅症の報告は散 見される ${ }^{1) 4}$. しかし，どの程度のずれをすべりとす るかはまちまちである. 我々は椎体の大きさには固体 差が大きいことから椎体前後径の $10 \%$ 以上をすべり ありとした。

すべりによる症状としては, 頝部痛, 神経根症状, 脊䯣症状のいずれも考えられるが，頚部痛がすべりの 直接の症状とするには，レントゲンだけでは極めて暧 昧といえる. また解剖学的に後方すべりと異なり前方 すべりでは椎間孔の狭小の程度は少ない．これに対し て脊䯣症状の出現は容易に理解できる ${ }^{2)}$. 佐藤ら ${ }^{4}$ む 示したようにすべり下位の椎体上縁とすべり椎間の黄 色靱帯のたくれこみが脊䯣圧迫の原因となる．その病 態を裏付ける MRI 所見は, 脊䯣症状 6 例中 3 例に認 められた。 また脊㖪症状の出現の有無は固有の脊柱管 の広さとすべりの程度の相対的な関係によることが予 測されるが今回の検討では前後径が $12 \mathrm{~mm}$ 以下の例 は 1 例にすぎず，本来の脊柱管はかならずしむ狭くな いことがうかがえた。 これは症例数が少ないことああ るが，不安定性など他の因子が脊䯣症状の出現に関与 している可能性が高いと思われた.

また, すべりそのものの発生に関しては，隣接椎の 変性による可動性の低下が大きな原因と思われた．特 に多椎間の連続した椎間の変性がある場合に，その上 位，ないし下位にすべりが発生すると考えられる. C3，C4 のすべりが多いことはこれまでの報告 ${ }^{3)} に も$ 一致する. C5 のすべりが存在しなかったことは，C5 /6が変性変化が最も早期に，しかも高度であるとい う報告 ${ }^{3)}$ をふまえると理解できる. 今回 C6 が 1 例, C7 が 1 例存在した. これは上位にすべりが多いとす る意見と異なる。これは下位䅡椎がレントゲン側面像 での肩との重なりの為に不明瞭な例が少なくないため 

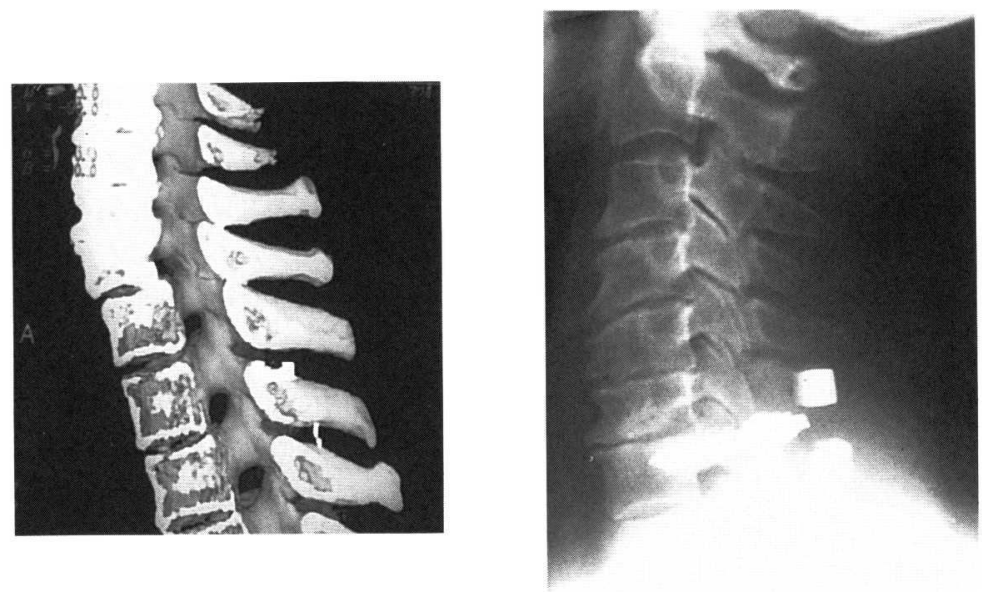

\section{図 2 症例 160 歳男性}

3D-CT でC7 の前方すべりを示す. C6 から Th1 の拡大術と Pedicular Screw System による後方固定術後 26 ケ月で $86 \%$ の改善率を維持している.
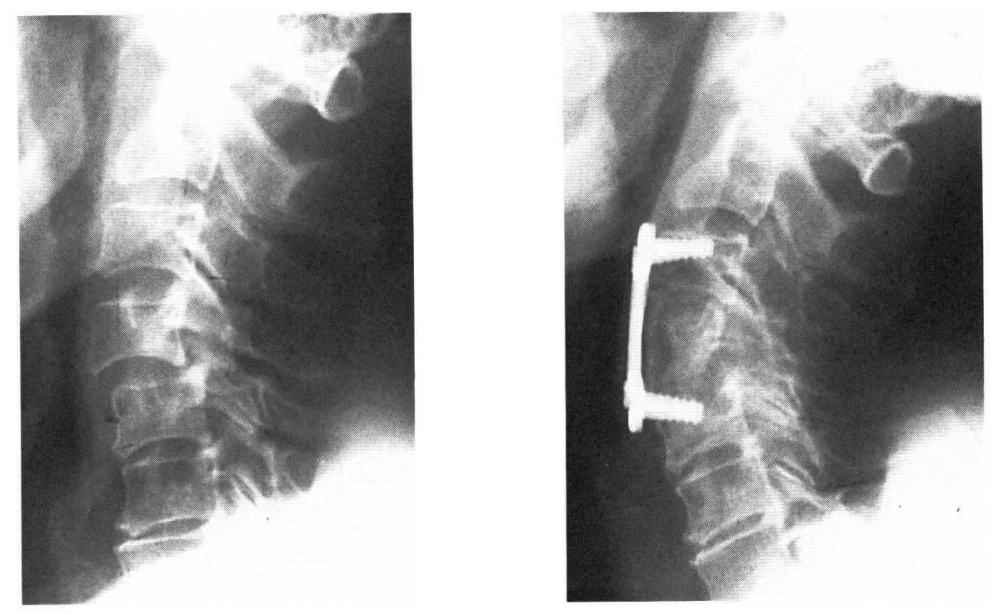

図 3 症例 275 歳男性

C4すべりに対してプレートを使用した前方除圧固定術を行った．罹病期間が 3 年 と長く改善率は $56 \%$ に留まっている.

と推測される. 従って下位頝椎でのすべり例は, ある 程度の頻度で存在することが推察される.

一方手術は脊髄症状のために適応となることが多い， Deburge ら ${ }^{1)}$ は局所症状に対しても積極的に手術を 行っているが, 先にあ述べたように責任高位がすべり 部位であることを決定することは容易ではなく自験例 で局所症状に対して手術を行った例はない.

手術法は腰椎変性すべりと同様に理論的には多くの
方法が考えられる. 我々は, すべり部位に限局した脊 骾圧迫の場合には限局した手術を行い，すべり部位以 外でも脊䯣圧迫が強い場合には脊柱管拡大術を行って いるが，高踰者が多い点を考えれば，脊柱管拡大術の 適応はより広いものと思われる. しかし，不安定性の 存在した C4 すべりで術後の一過性 C5 麻痺を経験し たので，不安定性のある場合は，固定や椎間孔の拡大 を考慮する必要がある. 
ま と め

1．変性変化による前方すべりを伴う頚䯣症手術例 6 例について検討した.

2. すべりはC3，C4 に多いが下位頚椎にも存在す る.

3.すべり部位のみが脊䯣症状の発現に関与してい たのは 6 例中 3 例であった.

4.すべり部位が限局している場合には固定術が, すべり部位以外にも圧迫が高度な場合には脊柱管拡大 術が適応となるが，広範囲の圧迫に不安定性がある場 合には工夫が必要である.

\section{参 考 文 献}

1) Deburge, A. K., Guigui M. P. : Unstable Degenerative Spondylolisthesis of the Cervical Spine. J. Bone Joint Surg. 77-B : 122-125, 1995.

2) Epstein J. A., et al. : Myelopathy in Cervical Spondylosis with Vertebral Subluxation and Hyperlordosis. J. Neurosurg. 32 : 421-426, 1970.

3) Hayashi H., et al. : Etiologic Factors of Myelopathy. A Radiographic Evaluation of the Aging Changes in the Cervical Spine. Clin Orthop ; 214, 200-209, 1987.

4）佐藤 純ほか：頚椎前方すべりによる頝部脊髄症. 整, 災外 $39: 1153-1158,1996$. 